\title{
Organizational Ambidexterity Practices \\ to Achieve Strategic Agility in Sports Clubs
}

\section{Assistant Professor Dr./ Reham Amin Hamza Shehab • Research Problem and Important:}

Under current developments and their effects, may organizations face accelerated and successive changes in their internal and external environments which requires a management characterized by organizational Ambidexterity to predict changes and respond to swiftly to achieve survival and continuity.

Zabiegalski (2015) indicates that Ambidexterity may achieve balance between explorative and usable activities coincidently (49:21).

Jacobsson, Oesterbeck (2018), Julian Allen, Samuel Hunter (2018) define organizational Ambidexterity as an attempt to use current resources and exploring new capacities (43:17), (47:270).

Michael Tushman et al (2016) identify dimensions of proficient organizations as follows:

Structural Ambidexterity, use Ambidexterity, and exploration Ambidexterity (46:163)

Bettina Buchel, Rhoda Davidson (2019) agreed with Amanda Setili (2017) on defining strategic Agility as the ability to reshaping the organizational strategy dynamically in the variable environment, through observation and continued sensation of the organization's environment and adapting with customers' desire. (38:7), (37:36) John P. Kotter (2014), Yves Doz, Mikko Kosonen (2008) identify main factors of strategic Agility in: strategic sensibility, joint responsibility, resources flow (42:38), (48:29)

The researcher reached the research problem through supervising department of sports administration and contributing to executing many activities as the researcher found that these clubs developed many buildings and updated many services and activities where these clubs able know opportunities available to meet beneficiaries' needs and guaranteeing survival.

Also the researcher interviewed (12) persons represented by members of clubs board's under research, executive managers and administrators to identify organizational Ambidexterity practice whose most important results were strong club's attempt to be involved in new sports activity in markets and keenness to offer new services to meet beneficiaries' needs and desires and through looking into many literature results such as results of study of Gawad Mohsen Rady, Masna Tawfik Abdel Hassan El Mosowy (2019) (13), Mahmoud Abdel Aziz Mansy (2018) (16), Lamis Aref Abdrabou El Mahsna (2017) (15), Adel Hady El Boghdad, Heidar Gassem El

- Assistant Professor, Department of Sports Administration, Faculty of Physical Education for Girls - Alexandria University 
Gaboury (2015) (4), Daniel Lee et al (2015) (40), Chu et al (2011) (39), Menguc, Bulent \& Auh, Seigyoung (2008) (45), which indicates the availability of usable activity practice more than exploration activities, statistical significant effect of organizational Ambidexterity in achieving strategic swiftness, which study of Mohamed Ibrahim Sowis, Ibrahim Abd Selim Abdeen (2019) (26), Youssef Hagim El Taei, Amer Abdel Karim El Zabhawy, Aly Hamid Hendy El Aly (2016) (35) recommended the importance of holding workshops to inform employees of organizational Ambidexterity concept and its importance.

Accordingly, the researcher could formulate this thesis subject titled:

\section{Organizational Ambidexterity Practices to Achieve Strategic Agility in Sports Clubs}

\section{Research Objective:}

Identifying effect of organizational Ambidexterity practice for achieving strategic Agility in sports clubs through:

- Organizational Ambidexterity "Structural Ambidexterity, Use Ambidexterity, Exploration Ambidexterity.

- Strategic Agility Factors " strategic sensibility, joint responsibility, resources flow,

\section{Research Procedures:}

Research Method: Survey Descriptive Method was used

Research Community: The research community is represented in chairman, board's members, executive managers, sports activity managers and administrator of some sports clubs in Egypt.

Research Sample: The total main research sample reached (224) subjects at (71.33

$\%$ ) of the whole research sample totaling (314) subjects.

Data collection Tools: Questionnaire Form designed by the Researcher

Scientific Coefficients of Questionnaire Form

First: Questionnaire Form Reliability 


\section{Calculating Internal Consistency Reliability Coefficient}

Table (1) Correlation Coefficients between each statement degree and its related dimensions and every statement and the total

degree of questionnaire $(N=43)$

\begin{tabular}{|c|c|c|c|c|c|c|c|c|c|c|c|}
\hline \multicolumn{4}{|c|}{$\begin{array}{c}\text { First Factor } \\
\text { Correlation Coefficient of the First Dimension } \\
\text { statement }\end{array}$} & \multicolumn{4}{|c|}{$\begin{array}{c}\text { First Factor (continued) } \\
\text { Correlation Coefficient of the Third Dimension } \\
\text { statement }\end{array}$} & \multicolumn{4}{|c|}{$\begin{array}{c}\text { Second Factor (continued) } \\
\text { Correlation Coefficient of the Second Dimension statement } \\
\text { (continued) }\end{array}$} \\
\hline $\mathbf{S}$ & $\begin{array}{l}\text { With First } \\
\text { Dimension }\end{array}$ & $\begin{array}{l}\text { With First } \\
\text { Factor }\end{array}$ & $\begin{array}{c}\text { With Total } \\
\text { Degree }\end{array}$ & $\mathbf{S}$ & $\begin{array}{l}\text { With Second } \\
\text { Dimension }\end{array}$ & $\begin{array}{l}\text { With First } \\
\text { Factor }\end{array}$ & $\begin{array}{c}\text { With Total } \\
\text { Degree }\end{array}$ & $\mathbf{S}$ & $\begin{array}{l}\text { With Third } \\
\text { Dimension }\end{array}$ & $\begin{array}{l}\text { With First } \\
\text { Factor }\end{array}$ & With Total Degree \\
\hline 1 & 0.375 & 0.452 & 0.435 & $25 / 1$ & 0.479 & 0.372 & 0.439 & 43 & 0.541 & 0.663 & 0.400 \\
\hline 2 & 0.449 & 0.375 & 0.509 & $25 / 2$ & 0.579 & 0.647 & 0.439 & $44 / 1$ & 0.493 & 0.598 & 0.712 \\
\hline 3 & 0.367 & 0.324 & $\mathbf{0 . 3 2 7}$ & $25 / 3$ & 0.486 & $\mathbf{0 . 6 3 3}$ & 0.546 & $44 / 2$ & 0.683 & 0.398 & 0.902 \\
\hline $4 / 1$ & 0.452 & 0.404 & 0.412 & $25 / 4$ & 0.459 & $\mathbf{0 . 5 8 7}$ & 0.519 & $44 / 3$ & 0.304 & 0.446 & 0.559 \\
\hline $4 / 2$ & 0.585 & 0.659 & 0.445 & 26 & 0.515 & 0.406 & 0.475 & $44 / 4$ & 0.533 & 0.678 & 0.752 \\
\hline 5 & 0.655 & 0.509 & 0.315 & 27 & 0.391 & 0.625 & 0.651 & $45 / 1$ & 0.539 & 0.348 & 0.758 \\
\hline 6 & 0.687 & 0.507 & 0.447 & $28 / 1$ & 0.385 & 0.588 & 0.645 & $45 / 2$ & 0.354 & 0.475 & 0.387 \\
\hline 7 & 0.561 & 0.429 & 0.521 & $28 / 2$ & 0.433 & 0.421 & 0.707 & $45 / 3$ & 0.398 & 0.454 & 0.617 \\
\hline $8 / 1$ & 0.404 & 0.504 & 0.636 & $28 / 3$ & 0.316 & 0.627 & 0.724 & 46 & 0.658 & 0.356 & 0.877 \\
\hline $8 / 2$ & 0.540 & 0.479 & 0.700 & 29 & 0.491 & 0.543 & 0.451 & \multicolumn{4}{|c|}{ Correlation Coefficient of the Third Dimension statement } \\
\hline 9 & $\mathbf{0 . 5 7 1}$ & 0.347 & $\mathbf{0 . 5 3 1}$ & 30 & $\mathbf{0 . 5 3 0}$ & 0.460 & 0.510 & 47 & 0.694 & 0.809 & 0.654 \\
\hline $10 / 1$ & 0.404 & 0.426 & 0.636 & $31 / 1$ & 0.694 & 0.415 & $\mathbf{0 . 6 5 4}$ & 48 & $\mathbf{0 . 5 7 0}$ & $\mathbf{0 . 6 5 4}$ & $\mathbf{0 . 5 3 0}$ \\
\hline $10 / 2$ & 0.555 & 0.482 & 0.515 & $31 / 2$ & $\mathbf{0 . 4 8 5}$ & 0.541 & 0.745 & 49 & $\mathbf{0 . 5 5 0}$ & $\mathbf{0 . 5 3 0}$ & $\mathbf{0 . 5 1 0}$ \\
\hline \multicolumn{4}{|c|}{$\begin{array}{c}\text { Correlation Coefficient of the Second Dimension } \\
\text { statement }\end{array}$} & $31 / 3$ & 0.524 & 0.462 & 0.684 & 50 & 0.551 & 0.510 & 0.511 \\
\hline 11 & 0.496 & 0.411 & 0.456 & $31 / 4$ & 0.631 & 0.714 & 0.691 & 51 & 0.882 & 0.360 & 0.842 \\
\hline 12 & $\mathbf{0 . 4 5 0}$ & $\mathbf{0 . 6 3 1}$ & 0.510 & \multicolumn{4}{|c|}{ Second Factor } & 52 & $\mathbf{0 . 8 1 7}$ & 0.672 & $\mathbf{0 . 7 7 7}$ \\
\hline 13 & 0.375 & 0.565 & $\mathbf{0 . 3 3 5}$ & \multicolumn{4}{|c|}{ Correlation Coefficient of the First Dimension statement } & 53 & $\mathbf{0 . 6 1 7}$ & 0.862 & 0.577 \\
\hline 14 & 0.522 & 0.492 & 0.482 & 32 & 0.450 & 0.343 & 0.310 & $54 / 1$ & 0.665 & 0.519 & 0.625 \\
\hline 15 & 0.498 & 0.443 & 0.658 & $33 / 1$ & 0.457 & 0.341 & 0.317 & $54 / 2$ & 0.897 & 0.712 & 0.857 \\
\hline 16 & 0.474 & 0.497 & 0.434 & $33 / 2$ & 0.553 & $\begin{array}{l}.321 \\
\end{array}$ & 0.313 & $54 / 3$ & 0.567 & 0.718 & $\mathbf{0 . 5 2 7}$ \\
\hline 17 & 0.291 & 0.313 & 0.591 & 34 & 0.478 & 0.308 & 0.338 & $54 / 4$ & 0.694 & 0.347 & 0.654 \\
\hline $18 / 1$ & 0.391 & 0.516 & 0.351 & 35 & 0.447 & 0.834 & 0.707 & $54 / 5$ & 0.387 & $\mathbf{0 . 5 7 7}$ & 0.347 \\
\hline $18 / 2$ & 0.367 & 0.429 & 0.327 & $36 / 1$ & 0.552 & 0.425 & 0.412 & & & & \\
\hline $18 / 3$ & 0.423 & 0.492 & 0.483 & $36 / 2$ & 0.427 & 0.305 & 0.313 & & & & \\
\hline 19 & 0.497 & 0.414 & 0.457 & $36 / 3$ & 0.425 & 0.308 & 0.315 & & & & \\
\hline $20 / 1$ & 0.522 & 0.679 & 0.482 & $36 / 4$ & 0.484 & 0.336 & 0.344 & & & & \\
\hline $20 / 2$ & 0.457 & 0.700 & 0.517 & $36 / 5$ & 0.390 & 0.652 & 0.650 & & & & \\
\hline $20 / 3$ & 0.306 & 0.592 & 0.366 & $36 / 6$ & 0.316 & 0.614 & 0.576 & & & & \\
\hline $21 / 1$ & 0.403 & 0.401 & 0.463 & $36 / 7$ & 0.342 & 0.632 & 0.602 & & & & \\
\hline $21 / 2$ & $\mathbf{0 . 3 2 0}$ & 0.375 & 0.480 & $36 / 8$ & 0.367 & 0.724 & 0.627 & & & & \\
\hline
\end{tabular}




\begin{tabular}{|c|c|c|c|c|c|c|c|c|}
\hline \multicolumn{4}{|c|}{$\begin{array}{c}\text { First Factor } \\
\text { Correlation Coefficient of the First Dimension } \\
\text { statement }\end{array}$} & \multicolumn{4}{|c|}{$\begin{array}{c}\text { First Factor (continued) } \\
\text { Correlation Coefficient of the Third Dimension } \\
\text { statement }\end{array}$} & $\begin{array}{c}\text { Second Factor (continued) } \\
\text { Correlation Coefficient of the Second Dimension statement } \\
\text { (continued) }\end{array}$ \\
\hline $21 / 3$ & 0.586 & 0.487 & 0.546 & $37 / 1$ & 0.452 & 0.704 & 0.312 & \\
\hline 22 & 0.432 & 0.451 & 0.408 & $37 / 2$ & 0.485 & 0.859 & 0.345 & \\
\hline $23 / 1$ & 0.495 & 0.495 & 0.555 & $37 / 3$ & 0.455 & 0.809 & 0.415 & \\
\hline $23 / 2$ & 0.502 & 0.498 & 0.462 & 38 & 0.587 & 0.707 & 0.447 & \\
\hline $23 / 3$ & 0.557 & 0.490 & 0.417 & \multicolumn{4}{|c|}{$\begin{array}{l}\text { Correlation Coefficient of the Second Dimension } \\
\text { statement }\end{array}$} & \\
\hline $24 / 1$ & 0.311 & 0.350 & 0.571 & 39 & 0.603 & 0.475 & 0.849 & \\
\hline $24 / 2$ & 0.457 & 0.441 & 0.417 & 40 & 0.475 & 0.351 & 0.694 & \\
\hline $24 / 3$ & 0.485 & 0.544 & 0.445 & 41 & 0.351 & 0.331 & 0.570 & \\
\hline $24 / 4$ & 0.328 & 0.483 & 0.588 & 42 & 0.331 & 0.332 & 0.550 & \\
\hline
\end{tabular}

$R_{g}$ value $(41,0.05)=0.288$ 
Second: Questionnaire Form Validity

\section{a. Calculation Questionnaire Form Validity Coefficient}

Table (9) Validity of Questionnaire Form by Split Half Method and

\section{Cronbach Alpha}

\begin{tabular}{|l|l|c|c|c|}
\hline \multicolumn{2}{|c|}{ Factors \& Dimensions } & Split Half - Method & \multirow{2}{*}{$\begin{array}{c}\text { Cronbach } \\
\text { Alpha }\end{array}$} \\
\cline { 3 - 4 } \multicolumn{2}{|l|}{} & $\begin{array}{c}\text { Spearman - } \\
\text { Brown }\end{array}$ & Guttman & \\
\hline First Factor & $\begin{array}{l}\text { Structural } \\
\text { Ambidexterity }\end{array}$ & $\mathbf{0 . 7 4 0}$ & $\mathbf{0 . 7 4 0}$ & $\mathbf{0 . 7 5 4}$ \\
\hline Second Factor & Use Ambidexterity & $\mathbf{0 . 7 4 7}$ & $\mathbf{0 . 7 3 4}$ & $\mathbf{0 . 7 8 3}$ \\
\hline Third Factor & $\begin{array}{l}\text { Exploration } \\
\text { Ambidexterity }\end{array}$ & $\mathbf{0 . 8 3 0}$ & $\mathbf{0 . 8 3 4}$ & $\mathbf{0 . 7 6 0}$ \\
\hline \multicolumn{1}{|c|}{ First Factor: Organizational Ambidexterity } & $\mathbf{0 . 7 5 3}$ & $\mathbf{0 . 7 7 2}$ & $\mathbf{0 . 8 7 7}$ \\
\hline First Dimension & Strategic sensibility & $\mathbf{0 . 7 0 7}$ & $\mathbf{0 . 7 0 0}$ & $\mathbf{0 . 7 1 7}$ \\
\hline Second Dimension & Joint Responsibility & $\mathbf{0 . 7 4 5}$ & $\mathbf{0 . 7 0 7}$ & $\mathbf{0 . 7 7 5}$ \\
\hline Third Dimension & Resources Flow & $\mathbf{0 . 7 5 3}$ & $\mathbf{0 . 7 7 2}$ & $\mathbf{0 . 7 8 3}$ \\
\hline \multicolumn{2}{|r|}{ Second Factor: Strategic Agility Values } & $\mathbf{0 . 7 3 0}$ & $\mathbf{0 . 7 7 5}$ & $\mathbf{0 . 8 2 8}$ \\
\hline \multicolumn{2}{|r|}{ Total Questionnaire Degree } & $\mathbf{0 . 7 9 8}$ & $\mathbf{0 . 7 6 0}$ & $\mathbf{0 . 8 0 7}$ \\
\hline
\end{tabular}

\section{Statistical Treatment:-}

"Repetition and percentage, correlation coefficient, validity coefficient by split half method, validity coefficient by Cronbach alpha method, value $\left(\mathrm{K}^{2}\right)$, analyzing contrast and effect range results by using $\left(\eta^{2}\right)$ domination percentage, valid significant differences test for Tukey (H.S.D), correlation matrix and effect results by using determination coefficient $\left(\mathrm{r}^{2}\right)$. 


\section{Results Discussion}

Table (9) Results of Repetition Percentage, predominance percentage, $\left(K^{2}\right)$ value for responding on the first

factor: Organizational Ambidexterity - First Dimension: Structural Ambidexterity

\begin{tabular}{|c|c|c|c|c|c|c|c|c|c|c|c|}
\hline \multirow[b]{2}{*}{$\mathbf{S}$} & \multirow[b]{2}{*}{ Statement Content } & \multicolumn{3}{|c|}{ Chairman $(\mathrm{N}=114)$} & \multicolumn{3}{|c|}{ Executive Managers $(\mathrm{N}=\mathbf{2 9})$} & \multicolumn{3}{|c|}{ Administrators $(\mathrm{N}=\mathbf{8 1})$} & \multirow[b]{2}{*}{$\mathrm{K}^{2}$ value } \\
\hline & & $\begin{array}{c}\text { Agreeing } \\
(\%)\end{array}$ & $\begin{array}{c}\text { Disagreeing } \\
(\%)\end{array}$ & $\begin{array}{l}\text { predominance } \\
\text { percentage }\end{array}$ & $\begin{array}{c}\text { Agreeing } \\
(\%)\end{array}$ & $\begin{array}{c}\text { Disagreeing } \\
(\%)\end{array}$ & $\begin{array}{c}\text { predominance } \\
\text { percentage }\end{array}$ & $\begin{array}{c}\text { Agreeing } \\
(\%)\end{array}$ & $\begin{array}{c}\text { Disagreeing } \\
(\%)\end{array}$ & $\begin{array}{c}\text { predominance } \\
\text { percentage }\end{array}$ & \\
\hline \multicolumn{12}{|c|}{$\begin{array}{l}\text { The sports club organizational structure has the } \\
\text { following characteristics: }\end{array}$} \\
\hline 1 & $\begin{array}{l}\text { Authority's lines flows clearly inconformity } \\
\text { with an effective communication between all } \\
\text { the club's departments }\end{array}$ & 86.84 & 13.16 & 93.42 & 82.76 & 17.24 & 91.38 & 75.31 & 24.69 & 87.65 & 4.303 \\
\hline 2 & $\begin{array}{l}\text { The clarity of occupational description of } \\
\text { different administrative level employees. }\end{array}$ & 89.47 & 10.53 & 94.74 & 75.86 & 24.14 & 87.93 & 48.15 & 51.85 & 74.07 & 40.971 \\
\hline 3 & $\begin{array}{l}\text { Work tasks are suitable for number of } \\
\text { employees in sports activity department and } \\
\text { this responsibilities }\end{array}$ & 77.19 & 22.81 & 88.60 & 72.41 & 27.59 & 86.21 & 41.98 & 58.02 & 70.99 & 26.503 \\
\hline 4 & $\begin{array}{l}\text { The club's administrative units are } \\
\text { sufficient for: }\end{array}$ & & & & & & & & & & \\
\hline $4 / 1$ & Achieving the club's objectives & 78.95 & 21.05 & 89.47 & 86.21 & 13.79 & 93.10 & 49.38 & 50.62 & 74.69 & 23.941 \\
\hline $4 / 2$ & Covering all the club's different activities & 80.70 & 19.30 & 90.35 & 79.31 & 20.69 & 89.66 & 70.37 & 29.63 & 85.19 & 2.955 \\
\hline 5 & Each administrative unit has a minor & 79.82 & 20.18 & 89.91 & 75.86 & 24.14 & 87.93 & 40.74 & 59.26 & 70.37 & 33.546 \\
\hline 6 & $\begin{array}{l}\text { There is an organizational regulation } \\
\text { clarifying the relationships between } \\
\text { different administrative levels employees }\end{array}$ & 86.84 & 13.16 & 93.42 & 68.97 & 31.03 & 84.48 & 45.68 & 54.32 & 72.84 & 37.959 \\
\hline 7 & $\begin{array}{l}\text { Forming committees and team works from } \\
\text { all departments to study the club's needs } \\
\text { permanently }\end{array}$ & 73.68 & 26.32 & 86.84 & 68.97 & 31.03 & 84.48 & 44.44 & 55.56 & 72.22 & 17.868 \\
\hline 8 & $\begin{array}{l}\text { Creating new departments to suit the } \\
\text { increase: }\end{array}$ & & & & & & & & & & \\
\hline $8 / 1$ & Work Tasks & 71.93 & 28.07 & 85.96 & 89.66 & 10.34 & 94.83 & 85.19 & 14.81 & 92.59 & 7.292 \\
\hline $8 / 2$ & Number of employees & 71.05 & 28.95 & 85.53 & 82.76 & 17.24 & 91.38 & 69.14 & 30.86 & 84.57 & 2.038 \\
\hline 9 & $\begin{array}{l}\text { Combining some departments to avoid } \\
\text { specialties duality }\end{array}$ & 78.95 & 21.05 & 89.47 & 82.76 & 17.24 & 91.38 & 72.84 & 27.16 & 86.42 & 1.583 \\
\hline 10 & $\begin{array}{l}\text { The club's supreme management tries to } \\
\text { repair and develop according to changes in }\end{array}$ & & & & & & & & & & \\
\hline $10 / 1$ & Internal environment & 81.58 & 18.42 & 90.79 & 65.52 & 34.48 & 82.76 & 48.15 & $\mathbf{5 1 . 8 5}$ & 74.07 & 24.145 \\
\hline $10 / 2$ & External environment & 85.96 & 14.04 & 92.98 & 62.07 & 37.93 & 81.03 & 41.98 & 58.02 & 70.99 & 41.783 \\
\hline
\end{tabular}

Value of $K^{2} g(2,0.05)=5.99$ 
From table No. (9) there are statistical significant differences between the research sample response on all the dimension statements as calculated $\mathrm{K}^{2}$ value was higher than tabular value at significant level (0.05) and ranged between (7.292:41.783) except for statements (1, 4/2, $8 / 2$, 9) as calculated $\mathrm{K}^{2}$ value was less than its tabular value and ranged between (1.583:4.303)

This agrees with results of Maged El Fera, Mahmoud El Shanty (2008) (19) and Mahmoud Ibrahim (2006) (17) that any organizational structure disorder may affect methods of decision making.

As it is clear from statements number $(2,3,4 / 1)$ how far research sample opinions are disagreeing as responses of chairmen and executive managers were agreeing by agreement percentage between (72.41: $89.47 \%$ ) on that the club's organizational structure is characterized by clarity and job description, while work tasks are suitable for number of employees, we find that administrators' responses were (non agreeing) as agreeing percentage ranged between (41.98:49.15\%).

This agrees with study results of Mohamed Abdelfattah (2019) (25) Mohamed Hanfy Tibidi (2014) (24) that integration and cooperation between activities and different administrative units in the organization may assist in executing strategies efficiently and effectively.

From Statements number $(5,6,7,8 / 1)$ it is clear that as responses of chairmen and executive managers were agreement at percentage from (68.97:89.66\%) upon that there is a minor for every administrative unit, there is a regulation organizing the relationship between employees, we find that administrators responses was non agreement with an agreement percentage between (40.74: 85.19\%).

In this respect results of study of Rola Gawad (2018) (32), Ahmed Ghonim (2004) agree upon that manpower size increase over actual manpower size represents one of the most important occupational organizational problems (5:34)

Study of Khedwi Khalifa (2013) (14), Abbas Youssef (2005) (1) recommended the importance of administrative leadership's familiarity with strategic administration concept.

The researcher believes that structural Ambidexterity enable all club's leaderships and employees to optimal use of available opportunities and looking for new ones. 
Table (10) Results of Repetition Percentage, predominance percentage, $\left(\mathrm{K}^{2}\right)$ value for responding on the first factor:

Organizational Ambidexterity - Second Dimension: Use Ambidexterity

\begin{tabular}{|c|c|c|c|c|c|c|c|c|c|c|c|}
\hline \multirow[b]{2}{*}{$\mathbf{S}$} & \multirow[b]{2}{*}{ Statement Content } & \multicolumn{3}{|c|}{ Chairmen $(\mathrm{N}=114)$} & \multicolumn{3}{|c|}{ Executive Managers ( $(\mathrm{N}=29)$} & \multicolumn{3}{|c|}{ Administrators ( $\mathbf{N}=\mathbf{8 1}$ ) } & \multirow[b]{2}{*}{$\mathbf{K}^{2}$ value } \\
\hline & & $\begin{array}{c}\text { Agreeing } \\
(\%)\end{array}$ & $\begin{array}{c}\text { Disagreeing } \\
(\%)\end{array}$ & $\begin{array}{c}\text { Predominance } \\
\text { percentage }\end{array}$ & $\begin{array}{c}\text { Agreeing } \\
(\%)\end{array}$ & $\begin{array}{c}\text { Disagreeing } \\
(\%)\end{array}$ & $\begin{array}{c}\text { Predominance } \\
\text { percentage }\end{array}$ & $\begin{array}{c}\text { Agreeing } \\
(\%)\end{array}$ & $\begin{array}{c}\text { Disagreeing } \\
(\%)\end{array}$ & $\begin{array}{c}\text { predominance } \\
\text { percentage }\end{array}$ & \\
\hline 11 & $\begin{array}{l}\text { The club's management used } \\
\text { certain strategies to support the } \\
\text { club's objectives }\end{array}$ & 79.82 & 20.18 & 89.91 & 75.86 & 24.14 & 87.93 & 60.49 & 39.51 & 80.25 & 9.048 \\
\hline 12 & $\begin{array}{l}\text { The club's management confirms } \\
\text { making permanent amends to } \\
\text { improve the provided activities and } \\
\text { services }\end{array}$ & 92.98 & 7.02 & 96.49 & 89.66 & 10.34 & 94.83 & 66.67 & 33.33 & 83.33 & 24.316 \\
\hline 13 & $\begin{array}{l}\text { The club's management focuses on } \\
\text { increasing number of activities and } \\
\text { services provided currently to } \\
\text { beneficiaries }\end{array}$ & 87.72 & 12.28 & 93.86 & 86.21 & 13.79 & 93.10 & 55.56 & 44.44 & 77.78 & 28.713 \\
\hline 14 & $\begin{array}{l}\text { The club's management focuses on } \\
\text { developing employees' skills to } \\
\text { fulfill their tasks proficiently }\end{array}$ & 78.07 & 21.93 & 89.04 & 72.41 & 27.59 & 86.21 & 48.15 & 51.85 & 74.07 & 19.556 \\
\hline 15 & $\begin{array}{l}\text { The club's supreme administration } \\
\text { follows up results of employees' } \\
\text { development and training. }\end{array}$ & 85.96 & 14.04 & 92.98 & 75.86 & 24.14 & 87.93 & 45.68 & 54.32 & 72.84 & 37.189 \\
\hline 16 & $\begin{array}{l}\text { The club's management focuses on } \\
\text { reducing costs of internal } \\
\text { operations }\end{array}$ & 93.86 & 6.14 & 96.93 & 82.76 & 17.24 & 91.38 & 44.44 & 55.56 & 72.22 & 62.133 \\
\hline 18 & $\begin{array}{l}\text { The club has a suitable } \\
\text { compensation regulation to } \\
\text { motivate employee to: }\end{array}$ & & & & & & & & & & \\
\hline $18 / 1$ & Do the best to achieve objectives & 91.23 & 8.77 & 95.61 & 93.10 & 6.90 & 96.55 & 45.68 & 54.32 & 72.84 & 58.221 \\
\hline $18 / 2$ & Optimal use of available resources & 90.35 & 9.65 & 95.18 & 79.31 & 20.69 & 89.66 & 44.44 & 55.56 & 72.22 & 50.666 \\
\hline $18 / 3$ & Work development & 87.72 & 12.28 & 93.86 & 86.21 & 13.79 & 93.10 & 41.98 & 58.02 & 70.99 & 51.856 \\
\hline 19 & $\begin{array}{l}\text { Information technology and modern } \\
\text { techniques are used to improve } \\
\text { performance in all departments of } \\
\text { the club }\end{array}$ & 73.68 & 26.32 & 86.84 & 62.07 & 37.93 & 81.03 & 35.80 & 64.20 & 67.90 & 28.164 \\
\hline 20 & $\begin{array}{l}\text { The club management focus on } \\
\text { compiling training programs } \\
\text { according to the following: }\end{array}$ & & & & & & & & & & \\
\hline $20 / 1$ & Their training needs & 74.56 & 25.44 & 87.28 & 93.10 & 6.90 & 96.55 & 30.86 & 69.14 & 65.43 & 52.373 \\
\hline $20 / 2$ & Evaluation results & 78.07 & 21.93 & 89.04 & 79.31 & 20.69 & 89.66 & 37.04 & 62.96 & 68.52 & 37.994 \\
\hline $20 / 3$ & Occupational Task Nature & 79.82 & 20.18 & 89.91 & 79.31 & 20.69 & 89.66 & 39.51 & 60.49 & 69.75 & 36.848 \\
\hline
\end{tabular}




\begin{tabular}{|c|c|c|c|c|c|c|c|c|c|c|c|}
\hline \multirow[b]{2}{*}{$\mathbf{S}$} & \multirow[b]{2}{*}{ Statement Content } & \multicolumn{3}{|c|}{ Chairmen $(\mathrm{N}=114)$} & \multicolumn{3}{|c|}{ Executive Managers $(\mathrm{N}=29)$} & \multicolumn{3}{|c|}{ Administrators $(\mathrm{N}=81$ ) } & \multirow[b]{2}{*}{$\mathrm{K}^{2}$ value } \\
\hline & & $\begin{array}{c}\text { Agreeing } \\
(\%)\end{array}$ & $\begin{array}{c}\text { Disagreeing } \\
(\%)\end{array}$ & $\begin{array}{l}\text { Predominance } \\
\text { percentage }\end{array}$ & $\begin{array}{c}\text { Agreeing } \\
(\%)\end{array}$ & $\begin{array}{c}\text { Disagreeing } \\
(\%)\end{array}$ & $\begin{array}{c}\text { Predominance } \\
\text { percentage }\end{array}$ & $\begin{array}{c}\text { Agreeing } \\
(\%)\end{array}$ & $\begin{array}{c}\text { Disagreeing } \\
(\%)\end{array}$ & $\begin{array}{c}\text { predominance } \\
\text { percentage }\end{array}$ & \\
\hline 21 & $\begin{array}{l}\text { The club's management is keen to } \\
\text { permanent measurement of: }\end{array}$ & & & & & & & & & & \\
\hline $21 / 1$ & Beneficiaries' Satisfaction & 97.37 & 2.63 & 98.68 & 96.55 & 3.45 & 98.28 & $\mathbf{8 1 . 4 8}$ & $\mathbf{1 8 . 5 2}$ & 90.74 & $\mathbf{1 6 . 4 8 4}$ \\
\hline $21 / 2$ & Employees' Satisfaction & 94.74 & 5.26 & 97.37 & 86.21 & 13.79 & 93.10 & 35.80 & 64.20 & 67.90 & 85.373 \\
\hline $21 / 3$ & Financial Aspects achievement & 96.49 & 3.51 & 98.25 & 89.66 & 10.34 & 94.83 & 39.51 & 60.49 & 69.75 & 85.828 \\
\hline 22 & $\begin{array}{l}\text { The club's supreme management } \\
\text { has a hot line to receive complaints } \\
\text { and answer any questions }\end{array}$ & 42.98 & 57.02 & 71.49 & 41.38 & $\mathbf{5 8 . 6 2}$ & 70.69 & 29.63 & 70.37 & 64.81 & 3.752 \\
\hline $23 / 1$ & $\begin{array}{l}\text { Players' registration in different } \\
\text { activities }\end{array}$ & 42.98 & 57.02 & 71.49 & 41.38 & 58.62 & 70.69 & 29.63 & 70.37 & 64.81 & 3.752 \\
\hline $23 / 2$ & $\begin{array}{l}\text { Informing beneficiaries of all the } \\
\text { club's activities }\end{array}$ & 96.49 & 3.51 & 98.25 & 96.55 & 3.45 & 98.28 & 97.53 & 2.47 & 98.77 & 0.181 \\
\hline $23 / 3$ & $\begin{array}{l}\text { Facilitating work inside the } \\
\text { administrative unit }\end{array}$ & 78.07 & 21.93 & 89.04 & 72.41 & 27.59 & 86.21 & 43.21 & 56.79 & 71.60 & 26.068 \\
\hline 24 & $\begin{array}{l}\text { The club's supreme management } \\
\text { keenness to: }\end{array}$ & & & & & & & & & & \\
\hline $24 / 1$ & $\begin{array}{l}\text { Allowing employees to take a part } \\
\text { in planning for sports activities and } \\
\text { programs }\end{array}$ & 78.95 & 21.05 & 89.47 & 93.10 & 6.90 & 96.55 & 41.98 & 58.02 & 70.99 & 39.474 \\
\hline $24 / 2$ & $\begin{array}{l}\text { Discussing with employees all } \\
\text { problems of work and suggesting } \\
\text { solutions according to their views }\end{array}$ & 89.47 & 10.53 & 94.74 & 96.55 & 3.45 & 98.28 & 35.80 & 64.20 & 67.90 & 76.799 \\
\hline $24 / 3$ & Fulfilling employees needs & 93.86 & 6.14 & 96.93 & 93.10 & 6.90 & 96.55 & 39.51 & 60.49 & 69.75 & 79.172 \\
\hline $24 / 4$ & Fulfilling beneficiaries needs & 86.84 & 13.16 & 93.42 & 89.66 & 10.34 & 94.83 & 91.36 & 8.64 & 95.68 & 0.996 \\
\hline
\end{tabular}

It is clear from table number (10) that there are statistical significant differences between the research sample on all statements of

dimension as $\mathrm{K}^{2}$ ranged between (9.048:85.373) and except for statements number (22, 23/1, 23/2, 24/4) as they were less than their tabular value and ranged between (0.181:3.752). It is clear from statements number (11:17) how far the research sample opinions differed where as responses of chairmen, executive managers agreed at (75.86:94.74\%) about the fact that the club management uses certain strategies to support objectives, making amends on a permanent bases to improve activities and services level while responses of administrators were (disagreeing) as agreement percentage ranged between (43.21:66.67 \%). 
Results of Studies of Reham Hamza (2015) (31) prove that sports clubs focus on developing activities on a permanent basis which may increase the provided services quality.

Moamen Shrafeldin recommends in his study (2012) (28) the importance of amending or correcting any disorder in the organization's process through permanent improvement. Also and from statements number $(181,18 / 2,18 / 3,19)$ contrast between the research sample opinions were proved as responses of chairmen and executive managers were agreement ranging between (62.07: 93.10\%) provided the club has a suitable compensation regulation to motivate employees to achieve objectives and optimal use of resources while responses of administrators were (disagreeing) at agreement percentage (35.80: $45.68 \%)$.

Hend Roushdy (2014) indicates that training strategy enhance individual skills (12:139), also Shawki Fouda (2005) (33) recommends the importance of measuring and rectifying financial and non financial performance.

But statement number $(22,23 / 1)$ proves the research sample agreement upon the supreme management's failure to avail a hot line to receive complaints and answer questions, non using electronic management in players' registration at low percentage from (29.63: 42.98).

Result of Study of Haitham Akl (2016) (9) proves disability to reserve and player's registration in sports activity service on the website.

The researcher believes that use Ambidexterity is the ability of using available opportunities efficiently. 
Table (11) Results of Repetition Percentage, predominance percentage, $\left(\mathrm{K}^{2}\right)$ value for responding on the First Factor: Organizational Ambidexterity - Third Dimension: Exploration Ambidexterity

\begin{tabular}{|c|c|c|c|c|c|c|c|c|c|c|c|}
\hline \multirow[b]{2}{*}{$\mathbf{S}$} & \multirow[b]{2}{*}{ Statement Content } & \multicolumn{3}{|c|}{ Chairmen (N = 114) } & \multicolumn{3}{|c|}{ Executive Managers ( $N=29)$} & \multicolumn{3}{|c|}{ Administrators ( $\mathrm{N}=\mathbf{8 1}$ ) } & \multirow[b]{2}{*}{$\mathbf{K}^{2}$ value } \\
\hline & & $\begin{array}{c}\text { Agreeing } \\
(\%)\end{array}$ & $\begin{array}{l}\text { Disagreein } \\
\mathrm{g}(\%)\end{array}$ & $\begin{array}{l}\text { Predominance } \\
\text { percentage }\end{array}$ & $\begin{array}{c}\text { Agreeing } \\
(\%)\end{array}$ & $\begin{array}{c}\text { Disagreeing } \\
(\%)\end{array}$ & $\begin{array}{l}\text { Predominance } \\
\text { percentage }\end{array}$ & $\begin{array}{c}\text { Agreeing } \\
(\%)\end{array}$ & $\underset{(\%)}{\text { Disagreeing }}$ & $\begin{array}{l}\text { Predominance } \\
\text { percentage }\end{array}$ & \\
\hline 25 & $\begin{array}{l}\text { The club's supreme management follow } \\
\text { scientific method in compiling future } \\
\text { strategies through: }\end{array}$ & & & & & & & & & & \\
\hline $25 / 1$ & Enhancing strong points & 90.35 & 9.65 & 95.18 & 79.31 & 20.69 & 89.66 & 97.53 & 2.47 & 98.77 & 9.540 \\
\hline $25 / 2$ & Identifying and treating weak points & 92.98 & 7.02 & 96.49 & 82.76 & $\mathbf{1 7 . 2 4}$ & 91.38 & 48.15 & 51.85 & 74.07 & 52.345 \\
\hline $25 / 3$ & $\begin{array}{l}\text { Seizing opportunity available in the clubs } \\
\text { external environment }\end{array}$ & 95.61 & 4.39 & 97.81 & 93.10 & 6.90 & 96.55 & 90.12 & 9.88 & 95.06 & 2.287 \\
\hline $25 / 4$ & Dealing with risks and threats & 87.72 & 12.28 & 93.86 & 68.97 & 31.03 & 84.48 & 45.68 & 54.32 & 72.84 & 39.942 \\
\hline 26 & $\begin{array}{l}\text { The club's management creates new } \\
\text { activities and services for beneficiaries }\end{array}$ & 93.86 & 6.14 & 96.93 & 96.55 & 3.45 & 98.28 & 79.01 & 20.99 & 89.51 & 12.527 \\
\hline 27 & $\begin{array}{l}\text { The club's management is able to market } \\
\text { new activities and services efficiency }\end{array}$ & 100.00 & 0.00 & 100.00 & 93.10 & 6.90 & 96.55 & 97.53 & 2.47 & 98.77 & 6.608 \\
\hline 28 & $\begin{array}{l}\text { There are laws and regulations to } \\
\text { support the club's investment } \\
\text { represented in: }\end{array}$ & & & & & & & & & & \\
\hline $28 / 1$ & Using many distribution channels & 89.47 & 10.53 & 94.74 & 96.55 & 3.45 & 98.28 & 95.06 & 4.94 & 97.53 & 2.923 \\
\hline $28 / 2$ & $\begin{array}{l}\text { Allowing the sponsoring company's posts } \\
\text { to be fixed during championships }\end{array}$ & 93.86 & 6.14 & 96.93 & 93.10 & 6.90 & 96.55 & 97.53 & 2.47 & 98.77 & 1.648 \\
\hline $28 / 3$ & $\begin{array}{l}\text { Allowing the sponsoring companies to } \\
\text { promote their products during } \\
\text { championships and sports events. }\end{array}$ & 86.84 & 13.16 & 93.42 & 79.31 & 20.69 & 89.66 & 98.77 & 1.23 & 99.38 & 12.044 \\
\hline 29 & $\begin{array}{l}\text { The club tries to attract new beneficiaries } \\
\text { through permanent development of } \\
\text { services and activities }\end{array}$ & 98.25 & 1.75 & 99.12 & 93.10 & 6.90 & 96.55 & 97.53 & 2.47 & 98.77 & 2.366 \\
\hline 30 & $\begin{array}{l}\text { Employees are motivated towards } \\
\text { creation and producing new ideas } \\
\text { supporting exploring new opportunities } \\
\text { and performance development }\end{array}$ & 88.60 & 11.40 & 94.30 & 89.66 & 10.34 & 94.83 & 32.10 & 67.90 & 66.05 & 76.832 \\
\hline 31 & Sports club budget allows to: & & & & & & & & & & \\
\hline $31 / 1$ & $\begin{array}{l}\text { Motivating players to develop local and } \\
\text { international level }\end{array}$ & 92.11 & 7.89 & 96.05 & 93.10 & 6.90 & 96.55 & 62.96 & 37.04 & 81.48 & 29.793 \\
\hline $31 / 2$ & $\begin{array}{l}\text { Attracting skilful and experienced } \\
\text { persons }\end{array}$ & $\mathbf{8 8 . 6 0}$ & 11.40 & 94.30 & 86.21 & 13.79 & 93.10 & 64.20 & 35.80 & 82.10 & 18.203 \\
\hline $31 / 3$ & Using foreign experiences & 67.54 & 32.46 & 83.77 & 62.07 & 37.93 & 81.03 & 48.15 & 51.85 & 74.07 & 7.482 \\
\hline $31 / 4$ & $\begin{array}{l}\text { Carrying out permanent researches to } \\
\text { expect future beneficiaries needs }\end{array}$ & 93.86 & 6.14 & 96.93 & 89.66 & 10.34 & 94.83 & 35.80 & 64.20 & 67.90 & 84.737 \\
\hline
\end{tabular}

Value of $K^{2}(2,0.05)=5.99$ 
It is clear from table number (11) that there are statistical significant differences between all the dimension statements as the calculates $\mathrm{K}^{2}$ value was higher that tabular value at significant level (0.05) and ranged between (6.608: 84.737) except for statement number $(25 / 3,28 / 1,28 / 2,29)$ as the calculated $\mathrm{K}^{2}$ value was less than its tabular value as it ranged between $(1.648: 2.923)$

From statements number $(25 / 2,25 / 4,30)$ it is clear how far research sample opinions are contradicting; while responses of chairmen and executive managers tended to agreement between $(68.97: 92.98 \%)$ about that the club's management shall follow scientific method of compiling strategies while we find that administrators' responses tended to (non agreement) as agreement percentage ranged between (32.10:48.15\%).

Abdel Rahim Mohamed (2012) states that identifying strong points may assist in optimal use of while identifying weak points may assist in getting rid of. (2:39)

Study of Fadia Gaghobi (2016) (8) recommends the importance of reviewing the establishments' strategic plans on a permanent basis and updating the same.

Statements number $(25 / 3,28 / 1,28 / 2,29)$ indicates the importance of research sample by a percentage between $(89.47,98.25 \%)$ on following scientific method by the supreme administration in compiling strategies.

This agrees with results of Mohamed Fawzy (2018) (23) of weak promotion of programs, activities and advertising campaigns of sports events.

Also study of Mohamed Alamin Boushair (2017) (22) recommends the importance of amending the legal aspect so that it encourages sports care.

Hassan Ahmed El Shafei, Yousria Ibrahim Moussa (2007) (11) indicates the importance of permanent attempt of achieving beneficiaries satisfaction by providing unique services.

The researcher believes that explorative Ambidexterity is represented in practices and creation sequence made by the club for providing new services to satisfy beneficiaries' needs. 
Table (12) Results of Repetition Percentage, predominance percentage, $\left(\mathrm{K}^{2}\right)$ value for responding on the Second Factor: Factors of Strategic Agility - First Dimension: Strategic Sensibility

\begin{tabular}{|c|c|c|c|c|c|c|c|c|c|c|c|}
\hline \multirow[b]{2}{*}{$\mathbf{S}$} & \multirow[b]{2}{*}{ Statement Content } & \multicolumn{3}{|c|}{ Chairmen $(N=114)$} & \multicolumn{3}{|c|}{ Executive Managers ( $N=29$ ) } & \multicolumn{3}{|c|}{ Administrators $(\mathrm{N}=\mathbf{8 1})$} & \multirow[b]{2}{*}{$\begin{array}{c}\mathbf{K}^{2} \\
\text { value }\end{array}$} \\
\hline & & $\begin{array}{c}\text { Agreeing } \\
(\%)\end{array}$ & $\begin{array}{l}\text { Disagreeing } \\
(\%)\end{array}$ & $\begin{array}{l}\text { Predominance } \\
\text { percentage }\end{array}$ & $\begin{array}{c}\text { Agreeing } \\
(\%)\end{array}$ & $\begin{array}{l}\text { Disagreeing } \\
(\%)\end{array}$ & $\begin{array}{l}\text { Predominance } \\
\text { percentage }\end{array}$ & $\begin{array}{c}\text { Agreeing } \\
(\%)\end{array}$ & $\begin{array}{l}\text { Disagreeing } \\
(\%)\end{array}$ & $\begin{array}{l}\text { Predominanc } \\
\text { e percentage }\end{array}$ & \\
\hline 32 & $\begin{array}{l}\text { The club management has a clear view for future } \\
\text { activities and how to deal with challenges internally and } \\
\text { externally }\end{array}$ & 93.86 & 6.14 & 96.93 & 72.41 & 27.59 & 86.21 & 85.19 & 14.81 & 92.59 & 10.943 \\
\hline 33 & The club's strategic objectives are consistent with: & & & & & & & & & & \\
\hline 33/1 & Strong and weak points in internal environment & 95.61 & 4.39 & 97.81 & 86.21 & 13.79 & 93.10 & 66.67 & 33.33 & 83.33 & 29.546 \\
\hline $33 / 2$ & Opportunities and threats in external environment & 87.72 & 12.28 & 93.86 & 82.76 & 17.24 & 91.38 & 67.90 & 32.10 & 83.95 & 11.754 \\
\hline 34 & $\begin{array}{l}\text { Strategic objectives were completed according to the } \\
\text { club's mission view }\end{array}$ & 96.49 & 3.51 & 98.25 & 93.10 & 6.90 & 96.55 & 69.14 & 30.86 & 84.57 & 31.065 \\
\hline 35 & $\begin{array}{l}\text { The club management's ability to compile an } \\
\text { alternative strategy to adapt with environmental } \\
\text { changes in community }\end{array}$ & 97.37 & 2.63 & 98.68 & 89.66 & 10.34 & 94.83 & $\mathbf{5 1 . 8 5}$ & 48.15 & 75.93 & 63.082 \\
\hline 36 & The club's strategy enables it to: & & & & & & & & & & \\
\hline $36 / 1$ & Represent the state in Arab and international forums & 85.96 & 14.04 & 92.98 & 96.55 & 3.45 & 98.28 & 81.48 & 18.52 & 90.74 & 3.973 \\
\hline $36 / 2$ & $\begin{array}{l}\text { Activating the role of commercial organizations in } \\
\text { sponsoring the club's championships and sports events }\end{array}$ & 78.07 & 21.93 & 89.04 & 89.66 & 10.34 & 94.83 & 92.59 & 7.41 & 96.30 & 8.362 \\
\hline $36 / 3$ & $\begin{array}{l}\text { Competitive advantages continuity in terms of activities } \\
\text { and services it offers. }\end{array}$ & 94.74 & 5.26 & 97.37 & 89.66 & 10.34 & 94.83 & 79.01 & 20.99 & 89.51 & 11.464 \\
\hline $36 / 4$ & $\begin{array}{l}\text { Establishing a club's website to provide a good } \\
\text { information system }\end{array}$ & 87.72 & 12.28 & 93.86 & 72.41 & 27.59 & 86.21 & 72.84 & 27.16 & 86.42 & 7.974 \\
\hline $36 / 5$ & $\begin{array}{l}\text { Providing supported aware leaderships for creative } \\
\text { thinking }\end{array}$ & 92.11 & 7.89 & 96.05 & 86.21 & 13.79 & 93.10 & 35.80 & 64.20 & 67.90 & 76.628 \\
\hline $36 / 6$ & $\begin{array}{l}\text { Reviewing the organizational structure dimensions and } \\
\text { carries out all required amends to attend variable } \\
\text { circumstances and new strategies. }\end{array}$ & 85.96 & 14.04 & 92.98 & 93.10 & 6.90 & 96.55 & 39.51 & 60.49 & 69.75 & 57.171 \\
\hline $36 / 7$ & $\begin{array}{l}\text { Adopting new administrative systems availing effective } \\
\text { participation to guarantee decisions efficiency. }\end{array}$ & 87.72 & 12.28 & 93.86 & 75.86 & 24.14 & 87.93 & 37.04 & 62.96 & 68.52 & 56.747 \\
\hline $36 / 8$ & $\begin{array}{l}\text { Adopting the basis of giving authorities and } \\
\text { responsibilities to prepare new future leadership cadres }\end{array}$ & 88.60 & 11.40 & 94.30 & 79.31 & 20.69 & 89.66 & 41.98 & 58.02 & 70.99 & $\mathbf{5 0 . 7 5 8}$ \\
\hline 37 & $\begin{array}{l}\text { The club's management is keen to employees } \\
\text { participation when having: }\end{array}$ & & & & & & & & & & \\
\hline $37 / 1$ & Strategic view, mission and objectives & 92.98 & 7.02 & 96.49 & 75.86 & 24.14 & 87.93 & 41.98 & 58.02 & 70.99 & 61.756 \\
\hline $37 / 2$ & Strategic plans & 95.61 & 4.39 & 97.81 & 79.31 & 20.69 & 89.66 & 45.68 & 54.32 & 72.84 & 64.009 \\
\hline $37 / 3$ & Strategic decisions & 74.56 & 25.44 & 87.28 & 62.07 & 37.93 & 81.03 & 48.15 & 51.85 & 74.07 & 14.261 \\
\hline 38 & $\begin{array}{l}\text { The club's management profits from corresponding } \\
\text { competing clubs when planning strategy }\end{array}$ & 86.84 & 13.16 & 93.42 & 79.31 & 20.69 & 89.66 & 86.42 & 13.58 & 93.21 & 1.123 \\
\hline
\end{tabular}

Value of $\mathrm{K}^{2}(2,0.05)=5.99$ 
From table number (12) it is clear that there are statistical significant differences between research groups responses to all the dimension statements as the calculated $\mathrm{K}^{2}$ value was higher that the tabular value at significant level (0.05) and ranged between (7.974: $76.628)$ with the exception statements number $(36 / 1,38)$.

It is clear from statements number $(32,33 / 1,33 / 2,34,35)$ how far the research sample opinions are contradictory while responses of chairmen and executive managers tended to agreement between (72.41: $97.37 \%$ ) provided the club's management has a clear view of future activities and how to deal with challenges while we find that administrators responses tended to agreement at low percentages between 51.85:85.19\%).

Mansour Mohamed El Ariki (2014) indicates that identifying the organizations strategic position through analyzing SWOT matrix (20:117).

Ayman El Derawy (2017) (6) recommends the importance of authorizing agents when preparing strategic plans.

It is clear from statements number $(36 / 5,36 / 6,36 / 36,7 / 8,137 / 1,37 / 2,37 / 3)$ how far the research sample opinions are contradictory provided the club's strategy avails the supported aware leaderships to creative thinking, reviewing the organizational structure dimensions to attend the variable circumstances with an agreement percentage between (62.07: $95.61 \%$ ) for board's members and managers while we find administrators responses refer to non agreement at percentage between (35.80: 48.15).

Results of study of Yasser Khalil (2017) (34) indicates that achieving the organizations competitive advantage and maintaining its survival can take place via developing organizational climate.

Matthias Nkuda (2017) (44) indicates that strategic Agility is a factor motivating rapid and instant response with selecting suitable strategy.

The researcher concludes that the club leaderships' strategic sensibility may avail an effective environment able to strategic prediction and permanence achievement. 
Table (13) Results of Repetition Percentage, predominance percentage, $\left(\mathrm{K}^{2}\right)$ value for responding on the Second Factor: Factors of

Strategic Agility - Second Dimension: Joint Responsibility "Group Obligation"

\begin{tabular}{|c|c|c|c|c|c|c|c|c|c|c|c|}
\hline \multirow[b]{2}{*}{$\mathbf{S}$} & \multirow[b]{2}{*}{ Statement Content } & \multicolumn{3}{|c|}{ Chairmen $(\mathrm{N}=114)$} & \multicolumn{3}{|c|}{ Executive Managers $(\mathrm{N}=29)$} & \multicolumn{3}{|c|}{ Administrators ( $\mathbf{N}=\mathbf{8 1}$ ) } & \multirow[b]{2}{*}{$\mathrm{K}^{2}$ value } \\
\hline & & $\begin{array}{c}\text { Agreeing } \\
(\%)\end{array}$ & $\begin{array}{c}\text { Disagreeing } \\
(\%)\end{array}$ & $\begin{array}{c}\text { Predominance } \\
\text { percentage }\end{array}$ & $\begin{array}{c}\text { Agreeing } \\
(\%)\end{array}$ & $\begin{array}{c}\text { Disagreeing } \\
(\%)\end{array}$ & $\begin{array}{c}\text { Predominance } \\
\text { percentage }\end{array}$ & $\begin{array}{c}\text { Agreeing } \\
(\%)\end{array}$ & $\begin{array}{c}\text { Disagreein } \\
\mathrm{g}(\%)\end{array}$ & $\begin{array}{c}\text { Predominance } \\
\text { percentage }\end{array}$ & \\
\hline 39 & $\begin{array}{l}\text { The club depends on joint responsibility to achieve } \\
\text { its works and objective in an integrated way }\end{array}$ & 92.11 & 7.89 & 96.05 & 82.76 & 17.24 & 91.38 & 46.91 & 53.09 & 73.46 & 52.159 \\
\hline 40 & $\begin{array}{l}\text { The club's management considers the employees } \\
\text { agreement with the club's strategy }\end{array}$ & 86.84 & 13.16 & 93.42 & 79.31 & 20.69 & 89.66 & 45.68 & 54.32 & 72.84 & 40.076 \\
\hline 41 & $\begin{array}{l}\text { There are work rules and clear instructions for all } \\
\text { club's departments }\end{array}$ & 93.86 & 6.14 & 96.93 & 75.86 & 24.14 & 87.93 & 50.62 & 49.38 & 75.31 & 48.398 \\
\hline 42 & $\begin{array}{l}\text { The club's management is able to execute the added } \\
\text { value operations regarding provide activities and } \\
\text { services. }\end{array}$ & 87.72 & 12.28 & 93.86 & 79.31 & 20.69 & 89.66 & 61.73 & 38.27 & 80.86 & 18.274 \\
\hline 43 & $\begin{array}{l}\text { The club's management considers the beneficiaries } \\
\text { feedback as a learning opportunity }\end{array}$ & 92.98 & 7.02 & 96.49 & 75.86 & 24.14 & 87.93 & 66.67 & 33.33 & 83.33 & 22.161 \\
\hline 44 & $\begin{array}{l}\text { Supporting mutual trust between the club's } \\
\text { department and beneficiaries through: }\end{array}$ & & & & & & & & & & \\
\hline $44 / 1$ & $\begin{array}{l}\text { Discussing their opinions according to their needs in } \\
\text { a democratic climate }\end{array}$ & 93.86 & 6.14 & 96.93 & 68.97 & 31.03 & 84.48 & 48.15 & 51.85 & 74.07 & 52.025 \\
\hline $44 / 2$ & $\begin{array}{l}\text { Participating in planning sports program and } \\
\text { submitted services systems }\end{array}$ & 87.72 & 12.28 & 93.86 & 72.41 & 27.59 & 86.21 & 39.51 & 60.49 & 69.75 & 51.103 \\
\hline $44 / 3$ & $\begin{array}{l}\text { Solving the problem and amending sports programs } \\
\text { in order to suit their desires }\end{array}$ & 90.35 & 9.65 & 95.18 & 79.31 & 20.69 & 89.66 & 40.74 & 59.26 & 70.37 & 57.704 \\
\hline $44 / 4$ & $\begin{array}{l}\text { Holding friendly meetings to discuss and respond to } \\
\text { their answers regarding provided and future } \\
\text { activities }\end{array}$ & 86.84 & 13.16 & 93.42 & 82.76 & 17.24 & 91.38 & 58.02 & 41.98 & 79.01 & 22.352 \\
\hline 45 & $\begin{array}{l}\text { Considering declaration and transparency in } \\
\text { obtaining information with: }\end{array}$ & & & & & & & & & & \\
\hline $45 / 1$ & Beneficiaries & 87.72 & 12.28 & 93.86 & 72.41 & 27.59 & 86.21 & 41.98 & 58.02 & 70.99 & 46.650 \\
\hline $45 / 2$ & Investors & 92.98 & 7.02 & 96.49 & 75.86 & 24.14 & 87.93 & 40.74 & 59.26 & 70.37 & 64.194 \\
\hline $45 / 3$ & Partners & 93.86 & 6.14 & 96.93 & 79.31 & 20.69 & 89.66 & 45.68 & 54.32 & 72.84 & 58.341 \\
\hline 46 & $\begin{array}{l}\text { Compiling time tables to execute all the club's tasks } \\
\text { and activities }\end{array}$ & 89.47 & 10.53 & 94.74 & 93.10 & 6.90 & 96.55 & 91.36 & 8.64 & 95.68 & 0.439 \\
\hline
\end{tabular}

Value of $\mathrm{K}_{\mathrm{g}}^{2}(2,0.05)=5.99$ 
From table number (13) there are statistical significant differences between the research sample responses to all the dimension statements as the calculated $\mathrm{K}^{2}$ value was more than the tabular value at significant level (0.05) and between (18.274: 64.194) and except for statement number (46) indicating that there should be time tables to fulfill all tasks and activities in the club with agreement percentage between (89.47:93.10) for all the research groups.

In this respect Adel Borkan (2011) (3) indicates the importance of compiling the time table under objectives execution priorities.

While it is clear from the remaining statements from (39:45/3) how far the research sample opinions are contradictory as responses of chairmen and executive managers tended to agreement between (68.97: $93.86 \%$ ) provided the club depends on joint responsibility for achieving its works, there are work rules and clear instructions, supporting mutual trust between the club's management and beneficiaries through discussing their opinions, participating in planning sports programs, holding friendly meetings to discuss and answer their questions regarding provided and future activities, declaration and transparency shall be considered to obtain information while we find that administrator's responses tended to agreement at low percentage between (39.51: 66.67 $\%)$.

Hassan Ahmed El Shafei, Abdellatif Ibrahim Bokhary (2007) mentions that sports organizations development aims at increasing their abilities to adapt with environment. $(10: 53)$

Reham Hamza (2015) (31), Alady Ammar (2010) (7) recommends the importance of availing an effective database inside clubs to guarantee transparency and declaration.

Study of Nasira Allawy (2011) (29) indicates that effective and competent execution of the study represents the most critical and important stage. 
Table (14) Results of Repetition Percentage, predominance percentage, $\left(\mathrm{K}^{2}\right)$ value for responding on the Second Factor: Factors of

Strategic Agility - Third Dimension: Resources Flow "Intrinsic"

\begin{tabular}{|c|c|c|c|c|c|c|c|c|c|c|c|}
\hline \multirow[b]{2}{*}{$\mathbf{S}$} & \multirow[b]{2}{*}{ Statement Content } & \multicolumn{3}{|c|}{ Chairmen $(\mathrm{N}=114)$} & \multicolumn{3}{|c|}{ Executive Managers $(\mathrm{N}=29)$} & \multicolumn{3}{|c|}{ Administrators ( $\mathrm{N}=81$ ) } & \multirow{2}{*}{$\begin{array}{c}\mathbf{K}^{2} \\
\text { value }\end{array}$} \\
\hline & & $\begin{array}{c}\text { Agreeing } \\
(\%)\end{array}$ & $\begin{array}{c}\text { Disagreeing } \\
(\%)\end{array}$ & $\begin{array}{c}\text { Predominance } \\
\text { percentage }\end{array}$ & $\begin{array}{c}\text { Agreeing } \\
(\%)\end{array}$ & $\begin{array}{c}\text { Disagreeing } \\
(\%)\end{array}$ & $\begin{array}{c}\text { Predominance } \\
\text { percentage }\end{array}$ & $\begin{array}{c}\text { Agreeing } \\
(\%)\end{array}$ & $\begin{array}{c}\text { Disagreeing } \\
(\%)\end{array}$ & $\begin{array}{c}\text { Predominance } \\
\text { percentage }\end{array}$ & \\
\hline 47 & $\begin{array}{l}\text { The club has enough financial resources to cover all its } \\
\text { operative needs. }\end{array}$ & 74.56 & 25.44 & 87.28 & 72.41 & 27.59 & 86.21 & 50.62 & 49.38 & 75.31 & 12.715 \\
\hline 48 & $\begin{array}{l}\text { The club management has a flexibility of distributing } \\
\text { its resources to different departments and profiting } \\
\text { from the capital to achieve strategic objectives. }\end{array}$ & 88.60 & 11.40 & 94.30 & 93.10 & 6.90 & 96.55 & 34.57 & 65.43 & 67.28 & 74.056 \\
\hline 49 & $\begin{array}{l}\text { The club's management has dynamic administrative } \\
\text { mechanisms to avail new resources }\end{array}$ & 87.72 & 12.28 & 93.86 & 89.66 & 10.34 & 94.83 & 85.19 & 14.81 & 92.59 & $\mathbf{0 . 4 7 0}$ \\
\hline 50 & $\begin{array}{l}\text { There are general rules focused on by the club's } \\
\text { management to allocate their resources }\end{array}$ & 85.96 & 14.04 & 92.98 & 86.21 & 13.79 & 93.10 & 88.89 & 11.11 & 94.44 & 0.380 \\
\hline 51 & $\begin{array}{l}\text { The club's management rationalize expense and } \\
\text { controls operative costs }\end{array}$ & 95.61 & 4.39 & 97.81 & 93.10 & 6.90 & 96.55 & 86.42 & 13.58 & 93.21 & 5.475 \\
\hline 52 & $\begin{array}{l}\text { The club's management focuses on a permanent } \\
\text { administrative control to improve mechanisms of } \\
\text { providing services to beneficiaries. }\end{array}$ & 89.47 & 10.53 & 94.74 & 93.10 & 6.90 & 96.55 & 81.48 & 18.52 & 90.74 & 3.766 \\
\hline 53 & $\begin{array}{l}\text { The club's management adopts permanent } \\
\text { improvement operations to develop performance. }\end{array}$ & 92.11 & 7.89 & 96.05 & 89.66 & 10.34 & 94.83 & 41.98 & 58.02 & 70.99 & 65.728 \\
\hline 54 & $\begin{array}{l}\text { There are cooperative relationships between the club's } \\
\text { management and: }\end{array}$ & & & & & & & & & & \\
\hline $54 / 1$ & Partners & 87.72 & 12.28 & 93.86 & 75.86 & 24.14 & 87.93 & 97.53 & 2.47 & 98.77 & 11.903 \\
\hline $54 / 2$ & Different clubs & 99.12 & 0.88 & 99.56 & 96.55 & $\mathbf{3 . 4 5}$ & 98.28 & 97.53 & 2.47 & 98.77 & 1.209 \\
\hline $54 / 3$ & Sports leagues & 99.12 & 0.88 & 99.56 & 96.55 & $\mathbf{3 . 4 5}$ & 98.28 & 98.77 & 1.23 & 99.38 & 1.167 \\
\hline $54 / 4$ & Youth and sports directorate & 99.12 & 0.88 & 99.56 & 96.55 & 3.45 & 98.28 & 98.77 & 1.23 & 99.38 & 1.167 \\
\hline $54 / 5$ & Ministry of youth and sports & 98.25 & 1.75 & 19.22 & 93.10 & 6.90 & 96.55 & 96.30 & 3.70 & 98.15 & 2.160 \\
\hline
\end{tabular}

Value of $\mathrm{K}_{\mathrm{g}}^{2}(\mathbf{2}, \mathbf{0 . 0 5})=5.99$

Table number (14) proved that statistical significant differences between a research sample responses to the dimension statements as $\mathrm{K}^{2}$ ranged between (11.903: 74.056) and except for statements number $(49,50,51,52,54 / 2,54 / 3,54 / 4,54 / 5)$ as the calculated $\mathrm{K}^{2}$ value was less than it tabular value. 
From statements number $(47,48,53)$ research sample's opinions are contradictory while responses of chairmen and executive managers tended to agreement ranged between $(72.41: 92.11 \%)$ on that the club shall have enough financial resources to cover all occupational needs, the club management adopt permanent improvement while we find that administrators' responses tended to low percentage agreement that reached $(34.57$, $50.62 \%)$.

Results of study of Mohamed Badr (2015) (21), Mahmoud Darwish (2011) (18) agreed upon weak governmental finance provided to sports organizations.

Study of Kassem Mazloum (2011) (30) recommends the importance of forming a team to clarify the mechanism of applying permanent improvement.

Statements number $(49,50,51,52,54 / 2,54 / 3,54 / 4,54 / 5)$ prove the agreement of the research sample opinion agreement with percentage (85.19: $99.12 \%)$ on that the club's management shall have dynamic administrative mechanisms to avail new resources, the club focuses on having a permanent control.

Mohamed El Khatib (2010) mentions that the optimal use of resources can't be achieved unless by means of rational management (27:47).

Study of Mohamed Badr (2015) (21), Zainb Aboud (2014) (36) recommends that organizations management requires high human capacities in addition to change in method of administration and organizational structures and availing sufficient financial resources to be able to develop their services.

Also the researcher concludes that strategic sensibility, joint responsibility, resources flow are characteristics that should be enjoyed by organizations specially sports clubs to reach strategic swiftness.

\section{Conclusions:}

\section{First Factor: Organizational Ambidexterity}

- Clubs management no care of reducing internal operations costs and lack of relative balance between usable performance and explorative performance.

- The club's supreme management non keenness to employees' participation in activities planning.

- Employees are not motivated towards inventions and having unique ideas supporting exploring new opportunities and performance development.

\section{Second Factor: Factors of Strategic Swiftness}


- Compiling strategic objectives according to the club's mission view, but the clubs management ability is limited in terms of having alternative strategies to adapt with environmental variables.

- The club's management is not keen to employees' participation when compiling view, mission, objectives, plans and strategic designs.

- Non considering declaration and transparency when obtaining information with all beneficiaries, investors and partners.

\section{Recommendations:}

The researcher advises of sports clubs managements to achieve balance between structural Ambidexterity, investment Ambidexterity and exploration to reach the strategic Agility case with focusing on individual as the first stage of achieving organizational Ambidexterity which reflects on the club strategic Agility through the following:-

- Holding training courses to increase leaderships' awareness inside the club of concept and importance of organizational Ambidexterity, strategic Agility and how to develop inside the club.

- Making environmental analysis to "internal and external environment" to identify and invest available opportunities and external threats to compile a strategy to reduce their effects.

\section{Bibliography}

\section{First: Arabic Bibliography:}

1. Abbas Mustafa Youssef (2005): The role of strategic management in raising performance efficiency in business establishments, Kenana Sugar Company Study, Unpublished PhD Thesis, Al-Neelain University. (https://www.mobt3ath.com/uplode/book/book-260.pdf)

2. Abdel Rahim Mohamed Abdel Rahim (2012): Strategy Management - Five Steps to Goal, Dar Al Maaref.

3. Adel Burkan (2011): The reality of planning in sports facilities in the province of Khenchela, published Master Thesis, Mohamed-Chérif Messaadia University, Algeria. (http://www.univ-soukahras.dz/ar/publication/article/250)

4. Adel Hadi Al-Baghdadi, Haider Jassim Al-Jubouri (2015): The Effect of Organizational Innovation in Achieving Strategic Resilience, A Comparative Field Study between Zain and Asia Telecom Companies in Iraq, Research Paper, Al-Qadisiyah Journal for Administrative and Economic Sciences, Vol (17), Issue (1) (https://www.iasj.net/iasj?func=fulltext\&aId=102818)

5. Ahmed Mohamed Ghoneim (2004): Introduction to Modern Management for Modernizing Organizations, Modern Library, Mansoura.

6. Ayman Hassan El-Derawy (2017): The impact of strategic planning on the performance of organizations: the leadership of organizations as an intermediary 
variable, an applied study on NGOs working in the Gaza Strip, research published in the Journal of the Islamic University of Economic and Administrative Studies, Volume (25), Issue (3), Al-Aqsa University. (https://www.academia.edu/37798248)

7. Elady Ammar (2010): The Role of Corporate Governance in Establishing the Rules of Transparency and Disclosure, First International Forum on Corporate Governance, Oum El Bouaghi University, Algeria.

8. Fadia Jagoubi (2016): The Role of Strategic Analysis (SWOT) in Improving the Organization's Performance, Unpublished Master Thesis, Faculty of Economic, Commercial and Management Sciences, Algerian Republic. (http://archives.univbiskra.dz/bitstream)

9. Haitham Fayez Mahmoud Aqel (2016): Strategy for e-sports marketing in sports clubs in the Arab Republic of Egypt, unpublished doctoral thesis, Faculty of Physical Education for Girls, Alexandria University

10. Hassan Ahmed El-Shafei, Abdellatif Ibrahim Bukhara (2007): Scientific Encyclopedia of Sports Management, Contemporary Approaches in Personnel Management and Organizational Development in Physical and Sports Education, 1st edition, Dar El Wafaa, Alexandria.

11. Hassan Ahmed El-Shafei, Yousria Ibrahim Mousa (2007): The requirements of the application of comprehensive quality standards in major sports clubs in Alexandria Governorate, a research published in the Journal of the Faculty of Arts, the thirty-first issue, No. (57), Alexandria University.

12. Hend Roushdy (2014): Professional Trainer, Strategies and Criteria for Successful Training, Al Shorouk for Publishing and Distribution.

13. Jawad Mohsen Radi, Muthanna Tawfiq Abdul Hassan Al-Musawi (2019): The Effect of Organizational Learning Mechanisms on Enhancing Strategic Agility, Research Published in Al-Muthanna Journal for Administrative and Economic Sciences, Volume (9) Issue (1), Iraq (https://muthjaes.net/wpcontent/uploads/2019/04)

14. khadaywaa Mohamed khalifa (2013): Model of administrative re-engineering youth welfare departments Ain Shams University, an unpublished master thesis, the Faculty of Physical Education for Boys, Helwan University.

15. Lamees Aref Abed Rabbo Al Mahasneh (2017): The Intermediary Role of Organizational Excellence in the Relationship between Dynamic Capabilities and Organizational Agility, An Empirical Study on Jordanian Pharmaceutical Industries, Unpublished Master Thesis, Faculty of Business, Middle East University, Amman. (https://meu.edu.jo/libraryTheses/59fdb75347def_1.pdf)

16. Mahmoud Abdel Aziz Mansy (2018): Intellectual Capital and its Effect on Organizational Innovation, An Empirical Study on Industrial Companies in 10th of Ramadan City, Egypt, Research published in the Arab Journal of Administrative Sciences, Volume (25), Issue (2), Kuwait University. (http://pubcouncil.kuniv.edu.kw/ajas/homear.aspx $? \mathrm{id}=8 \&$ Root=yes\&authid=1086)

17. Mahmoud Abdel Rahman Ibrahim (2006): The effect of the organizational climate on the performance of human resources, a field study on the ministries of the Palestinian National Authority in the Gaza Strip, unpublished Master Thesis, Faculty of Commerce, Islamic University of Gaza. (https://search.mandumah.com/Record/542117)

18. Mahmoud Omar Darwish (2011): Proposed marketing plan for the Egyptian Bodybuilding Championships, Unpublished Master Thesis, Faculty of Physical Education, Assiut University. 
19. Majed Mohamed Al-Farra, Mahmoud Abdel Rahman Al-Shanti (2008): The Effect of Organizational Climate on Human Resources Performance in the Ministries of the Palestinian National Authority in the Gaza Strip, Volume XVI, first issue. (http://www.iugaza.edu.ps/ara/research)

20. Mansour Mohamed Ismail Al Iraqi (2014): Strategic Management, Al-Amin for Publishing and Distribution, Sana'a.

21. Mohamed Badr Abdel Tawab (2015): A proposed strategy for marketing logistics activities in the Egyptian Volleyball Federation, unpublished doctoral thesis, Faculty of Physical Education, Assiut University.

22. Mohamed El Amine Bouchair (2017): The role of sports sponsorship in improving the mental image of the Algerian football teams in their audience - a field study on a sample of the audience of the Constantinople Sports Club, unpublished Master Thesis, Faculty of Social and Human Sciences, Al-Arabi Benmahidi University Oum El Bouaghi, Algeria. (http://bib.univoeb.dz:8080/jspui/handle/123456789/3891)

23. Mohamed Fawzy Abdel Moneim (2018): A proposed strategy for sports media for the Ministry of Youth and Sports in the Arab Republic of Egypt, unpublished doctoral thesis, Faculty of Physical Education for Girls, Alexandria University.

24. Mohamed Hanafi Mohamed Nour Tabidi (2014): The Role of Strategic Management in Raising the Efficiency and Effectiveness of Performance by Applying to Sudanese Telecommunication Companies, Research Published in Nile Basin Studies Journal, Volume 9, Issue 16, Al-Neelain University - Research and Development Department (https://search.mandumah.com/Record/609580)

25. Mohamed Ibrahim Abdel Fattah (2019): The relationship of organizational development with the institutional excellence of the Directorate of Youth and Sports in Damietta Governorate, unpublished doctoral thesis, Faculty of Physical Education for Girls, Alexandria University.

26. Mohamed Ibrahim Kamel Sweis, Ibrahim Abd Selim Abdin (2019): The Role of Business Intelligence Systems in Building Organizational Innovation by Applying to Banks Operating in Palestine, Research published in the Journal of the Islamic University for Economic and Administrative Studies, Volume (27), Issue (1) (http://journals.iugaza.edu.ps/index.php/IUGJEB/article/view/4607)

27. Mohamed Mahmoud El Khatib (2010): Financial Performance and its Impact on Dividends, 1st Edition, Dar Al-Hamed for Publishing and Distribution, Oman.

28. Mo'men Sharaf El Din (2012): The Role of Operations Management in Improving the Performance of the Economic Institution, Case Study, Unpublished Master Thesis, Faculty of Economic, Commercial and Management Sciences.

29. Nassira Allawi (2011): Strategic Vigilance as a Change Agent in the Foundation "Mobilis Case Study", Unpublished Master Thesis, Faculty of Economic, Commercial and Facilitation Sciences, University of Abi Bakr Belkaid, Tlemcen, Algeria. (http://dr-ama.com/wp-content/uploads/2015/12/ALLAOUINasera.mag_.pdf)

30. Qasim Mohamed Mazloum Al Enzi (2011): Using Deming Model in Achieving University Performance, A Field Study in the Faculty of Arts, University of Kufa, Research Published in Al-Kufi Studies Journal No. 21, Iraq. (http://search.shamaa.org/FullRecord?ID=121054)

31. Reham Amin Hamza (2015): Requirements for the application of governance in sports clubs, research published in the 16th International Scientific Conference, Faculty of Physical Education for Boys, Volume I, Helwan University. 
32. Rola Adel Jawad Al Qaisi (2018): Model of Organizational Structure Engineering in the Department of Physical Education and Sports - Iraq, Unpublished Master Thesis, Faculty of Physical Education for Girls, Alexandria University.

33. Shawky El Sayed Fouda (2005): A Proposed Framework for Evaluating Strategic Performance Assessment in the Modern Production Environment through the Balanced Scorecard Scale, Research Paper, Faculty of Commerce Journal, Volume I, Second Issue, Tanta University.

34. Yasser Mohamed Khalil (2017): Strategic Leadership and its Role in Improving the Competitive Advantage of Egyptian Universities, Ph.D. Published in the Journal of Scientific Research in Education, Issue XVIII, Girls College of Arts, Sciences and Education, Ain Shams University.

35. Yousef Hajim Al-Taie, Amer Abdel Karim Al-Zabhawi, Ali Hamid Hendi Al-Ali (2016): Strategic innovation and its role in the formation of skillful organizations, applied research of the views of a sample of university leaders in the University of Kufa, research published in the Journal of Qadisiyah Administrative and Economic Sciences, Volume (18), Issue (3). (https://www.iasj.net/iasj?func=fulltext\&aId=113455)

36. Zainab Abdul Razzaq Abboud (2014): Administrative Reform and the Requirements of Sustainable Development, Journal of the College of Management and Economics for Economic, Administrative and Financial Studies, No. 6, Volume II, University of Babylon, Iraq.

(https://www.researchgate.net/publication/309565245_alaslah_aladary_wmttlbat_ altnmyt_almstdamt)

\section{Second: Foreign references}

37. Amanda Setili (2017): Fearless Growth: The New Rules to Stay Competitive, Foster Innovation, and Dominate Your Markets, Weiser; 1st Edition

38. Bettina Buchel, Rhoda Davidson (2019): Strategic Agility - The Art of Piloting Initiatives, IMD International

39. Chu, Chih-Peng, Li, Ci-Rong and Lin, Chen-Ju (2011): "The joint effect of project-level exploratory and exploitative learning in new product development" European Journal of Marketing, Vol. (45) No. 4, pp. 53-550.

40. Daniel Lee; Vallabh Sambamurthy; Kai H. Lim \& Kwok Kee Wei )2015(: How Does IT Ambidexterity Impact Organizational Agility, Information Systems Research, 2015, vol. 26, issue 2, 398-417

41. Henderson, Rebecca, Ranjay Gulati and Michael Tushman, eds. (2015): Leading Sustainable Change: An Organizational Perspective. Oxford University Press

42. John P. Kotter (2014): Accelerate: Building Strategic Agility for a Faster-Moving World, Harvard Business Review Press

43. Josefine Jacobsson, Stephan Oesterbeck, Florence Schelling (2018): Ambidexterity and Decision Making, Managing the balance of exploitation and exploration in the context of lengthy product development cycles and product longevity, Linköping University, Sweden

44. Matthias Nkuda (2017): Strategic Agility and Competitive Advantage : Exploration of the Ontological, Epistemological and Theoretical Underpinnings , British Journal of Economics, Management \& Trade , 16(1.(

45. Menguc, Bulent and Auh, Seigyoung, (2008(: "The asymmetric moderating role of market orientation on the ambidexterity-firm performance relationship for 
prospectors and defenders" Industrial Marketing Management, Vol.(37), pp. 455470

46. Michael Tushman, O'Reilly \& Charles A. (2016): Lead and Disrupt: How to Solve the Innovator's Dilemma. Stanford, CA: Stanford Business Books

47. Samuel Hunter, Julian B. Allen, Rachel Heinen, Lily Cushenbery (2018):

Individual Creativity in the Workplace, A volume in Explorations in Creativity Research, Academic Press, USA

48. Yves Doz , Mikko Kosonen (2008): Fast Strategy: How strategic agility will help you stay ahead of the game 1st Edition

49. Zabiegalski, E. P.(2015): Learning Ambidexterity in Organization: The George Washington University Press 